\title{
Article \\ Analysis of Reject Water Formed in the Mechanical Dewatering Process of Digested Sludge Conditioned by Physical and Chemical Methods
}

\author{
Beata Bień *(D) and Jurand D. Bień (D)
}

check for updates

Citation: Bień, B.; Bień, J.D. Analysis of Reject Water Formed in the Mechanical Dewatering Process of Digested Sludge Conditioned by Physical and Chemical Methods. Energies 2022, 15, 1678. https:// doi.org/10.3390/en15051678

Academic Editor: Alok Kumar Patel

Received: 1 February 2022

Accepted: 22 February 2022

Published: 24 February 2022

Publisher's Note: MDPI stays neutral with regard to jurisdictional claims in published maps and institutional affiliations.

Copyright: (C) 2022 by the authors. Licensee MDPI, Basel, Switzerland. This article is an open access article distributed under the terms and conditions of the Creative Commons Attribution (CC BY) license (https:// creativecommons.org/licenses/by/ $4.0 /)$.
Faculty of Infrastructure and Environment, Czestochowa University of Technology, 42-200 Czestochowa, Poland jurand.bien@pcz.pl

* Correspondence: beata.bien@pcz.pl

\begin{abstract}
Reject water separated from digested sludge may be a potential source of nutrients due to its high content. However, most often, reject water after sludge dewatering is directed to sewage lines at wastewater treatment plants, negatively affecting their operation, especially in the biological part. The activities related to sludge conditioning before dewatering have a direct impact on the quality of the reject water. The reject water of raw digested sludge is characterized by very high concentrations of ammonium nitrogen, at $1718 \mathrm{mgN}^{-N_{4}}{ }^{+} / \mathrm{dm}^{3}$; phosphates, at $122.4 \mathrm{mgPO}_{4}{ }^{3-} / \mathrm{dm}^{3}$; and chemical oxygen demand (COD), at $2240 \mathrm{mgO}_{2} / \mathrm{dm}^{3}$. The objective of the research was to determine the impact of selected sludge conditioning methods on the quality of reject water obtained after sludge dewatering. The following parameters were analyzed in the reject water: the chemical oxygen demand (COD), phosphates, ammonium nitrogen, and total suspended solids (TSS). It has been observed that the sludge sonification process increases the content of impurities (COD, phosphates) in reject water with an increase in the amplitude of the ultrasonic field. On the other hand, the chemical reagents cause a decrease in the concentration of the pollutants with an increase of the chemical dose. It has been found that the inorganic coagulant PIX 113 gives much better results regarding the reduction of contamination than the polyelectrolyte Zetag 8180.
\end{abstract}

Keywords: reject water; quality; sewage sludge; conditioning; sonification

\section{Introduction}

One of the important processes involving the treatment of sewage sludge at wastewater treatments plants is anaerobic digestion. This is a biological process of decomposing organic substances in sewage sludge that leads to its stabilization. As a result, hydrophilic, highly hydrated, highly viscous, sanitary hazardous sewage sludge is transformed into easily dehydrated, thin, earthy sludge [1-5].

Reject water is formed during the dewatering of digested sludge, which is currently the subject of numerous studies [6-11]. Reject water treatment is a problem that wastewater treatment plants have to face. Most often, reject water is directed to a primary settling tank without prior pretreatment, mixed with the inflow, and then treated in a conventional wastewater treatment line. In that way, mainly due to a high concentration of nutrients, reject water disturbs the operation of the activated sludge chambers, which has a negative impact on the effectiveness of the biological part of the sewage treatment plant [12-16]. The quality of the reject water formed in the process of mechanical sludge dewatering depends considerably on the anaerobic sludge stabilization, the type of device used in the mechanical dewatering, its correct operation, and the proper selection of chemical reagents for the sludge conditioning prior to the dewatering. Reject water may contain from $10 \%$ to $25 \%$ of the nitrogen load and from $10 \%$ to $80 \%$ of the phosphorus load introduced to the treatment plant with the raw sewage [10,17-20], although the stream of reject water is 
relatively small $(0.4 \%$ to $1.2 \%$ of the volume of the wastewater flowing into the treatment plant) $[21,22]$.

The problem of reject water is that the concentrations of ammonia and orthophosphates are relatively high compared to the influent composition. A substantial part of nitrogen is redissolved during the digestion process; then, during the sludge dewatering, it is separated from the sludge as a liquid rich in nitrogen [23]. The situation is similar in the case of phosphorus; as much as $60 \%$ of the phosphorus removed from sewage can be rereleased during the hydrolysis of polyphosphates to the reject water [24,25]. The increasing amount of phosphorus with an equally high concentration of ammonium, nitrogen and magnesium ions constitutes a source of struvite [26-28]. Unfortunately, this is a common case in a number of wastewater treatment plants where large amounts of nitrogen and phosphorus are concentrated in the stream of reject water. Dissolved nutrients promote the formation of struvite, which occurs in pumps, sludge pipelines, dewatering devices and leachate pipelines. This results in a decrease in the effective cross-section of the pipelines. Additionally, the hard structure of struvite poses numerous operational problems. Struvite often mechanically blocks the inlets of pumps, aerators, screens and other technological devices. It has a serious impact on installations' reliability and efficiency, as well as their operating and maintenance costs. Struvite is a very unfavorable phenomenon known to be present in wastewater treatment plants. Therefore, many studies on reject water focus on the removal of nitrogen and phosphorus [29,30].

Podstawczyk et al. [31] proposed the removal of ammonium and orthophosphates from reject water generated during the dewatering of digested sewage sludge using an innovative two-stage method including an adsorption and membrane contactor system. The results showed that the use of a membrane system can lead to a $98.9 \pm 0.1 \%$ reduction in the ammonium concentration in the feed. The orthophosphate removal efficiency was also high, at $92.4 \pm 0.1 \%$. The mechanism of orthophosphate binding by eggshells modified with iron and zirconium oxide- based on a strong interaction between the positively charged adsorbent surface and negative orthophosphate ions in the solution-confirmed the effectiveness of the method. Podstawczyk et al. [31] concluded that the membrane system can be used for an effective removal of ammonium from reject water, while the adsorption process on metal oxide-modified eggshells can be an attractive alternative to conventional orthophosphate removal processes. Some of the researchers investigating reject water conduct research aim exclusively at removing nutrients from reject water, while others seek to find methods that would allow for the removal of these elements from reject waters but simultaneously to retrieve them to the largest extent. Given the growing demand for macronutrients such as nitrogen and phosphorus, and the environmental issues related to their production, the demand for effective nutrient recycling is growing [32-35]. Koskue et al. [33] successfully removed and recovered nitrogen from reject water using an electrochemical system combining electroconcentration and stripping. They achieved the highest nitrogen removal and recovery efficiencies in a three-chamber bioelectroconcentration cell with an ion-exchange membrane. In such systems, bacteria facilitate electrochemical reactions, such as the conversion of chemical energy into electrical energy. Then, the electrical energy can be used directly for nutrient recovery. This makes the process low-energy and chemical-free. Hence, the use of bioelectrochemical systems for nutrient recovery from liquid sources has gained considerable interest in recent years [36-39].

The selection of appropriate chemical and physical agents for the conditioning of digested sludge is one of the factors that have a significant impact on the quality of reject water [13,40-42]. These agents play two important roles: they increase the amount of water released by the sludge during dewatering in order to reduce the sludge volume and affect reject water quality, which is very important in the aspect of the further recovery of nutrients. Considering the importance of the reject water's quality, this paper presents the influence of independent and combined methods of sludge conditioning on the quality of the reject water obtained during the mechanical dewatering of digested sludge, which is a new approach to the issue. An ultrasonic field was used as a physical factor, and the 
chemical reagents used for the sludge conditioning prior to the mechanical dewatering process included Zetag 8180 polyelectrolyte and PIX 113 inorganic coagulant. Controlling the concentration of biogenic nutrients in reject water with the use of the applied methods of sludge conditioning is an important and practical aspect of the current research.

\section{Materials and Methods}

A digested sludge from a municipal, mechanical-biological wastewater treatment plant with a population equivalent (PE) of more than 100,000 was used for the study. The biological treatment of sewage was carried out using the method of activated sludge in the multifunctional biological reactors in which the process of the oxidation of organic compounds, nitrification, denitrification, and biological dephosphatation take place. A simultaneous precipitation of phosphates with the use of iron compounds occurs there, too. The technological scheme of sewage sludge processing includes the following unit processes:

- the thickening of primary sludge in primary sedimentation tanks,

- $\quad$ the final thickening of primary sludge in gravity thickeners,

- $\quad$ the thickening of excess sludge in a mechanical thickener,

- the single-stage mesophilic anaerobic digestion of the mixed sludge,

- the stabilization and thickening of digested sludge in open digestion chambers (ODC),

- $\quad$ the mechanical dewatering of digested sludge using belt filter presses, and

- thermal drying.

The sludge was collected at a mechanical dewatering station before the dewatering. In order to ensure the appropriate process conditions during the research, samples of the sludge were first stored in the fridge at $4^{\circ} \mathrm{C}$ and then warmed up to room temperature. The following scheme of the research was applied (Figure 1).

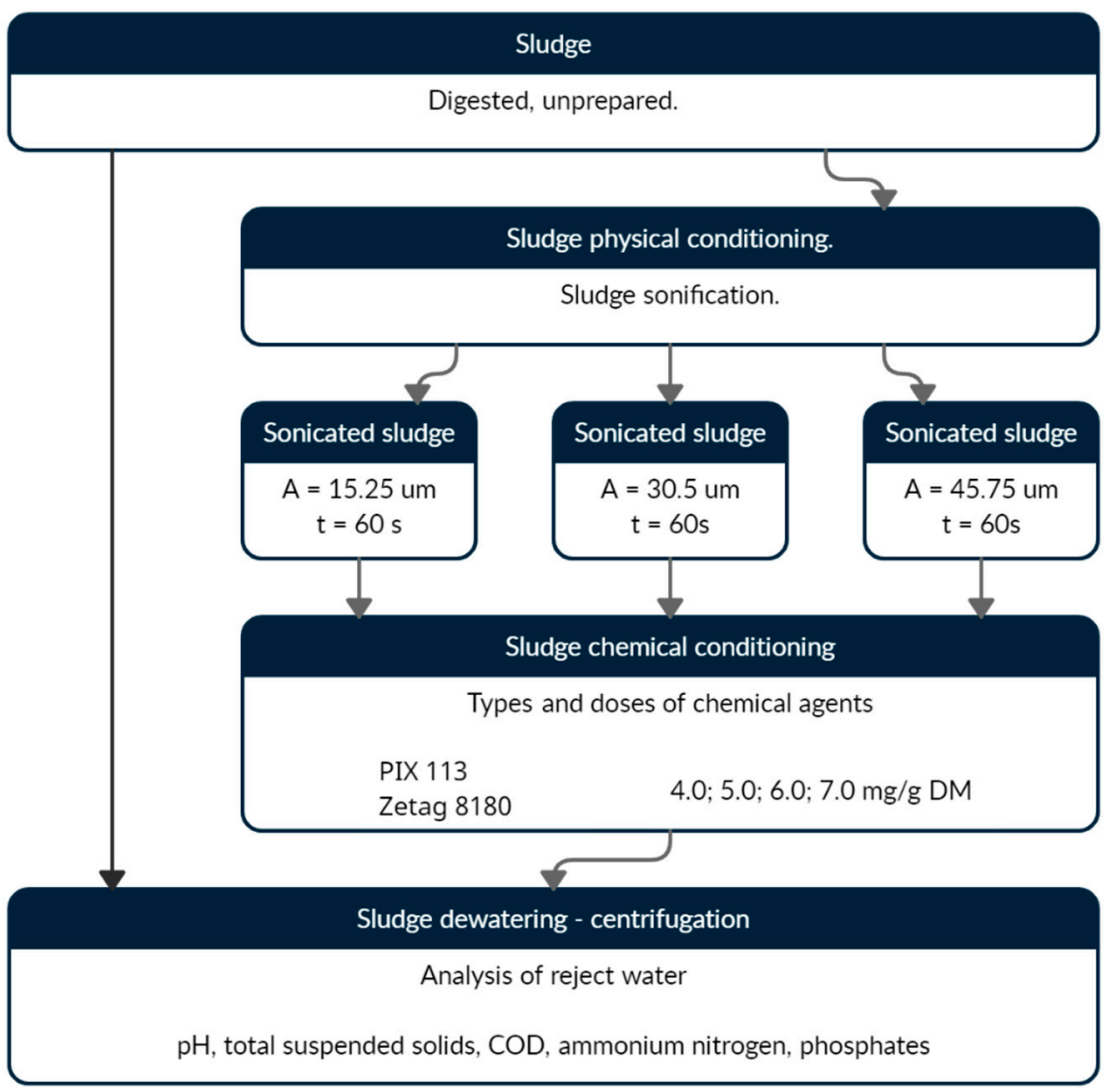

Figure 1. The scheme of the experimental research.

Initially, the physical conditioning of the sludge was carried out using various parameters of the ultrasonic field, and then the sludge was subjected to chemical conditioning. The 
ultrasonic disintegration was carried out using a Sonics VC750 microprocessor ultrasonic disintegrator at the frequency of $20 \mathrm{kHz}$. The volume of the sludge samples was $0.4 \mathrm{dm}^{3}$, and the sonication process used three different amplitudes: $\mathrm{A}_{1}=15.25 \mu \mathrm{m}, \mathrm{A}_{2}=30.5 \mu \mathrm{m}$, and $A_{3}=45.75 \mu \mathrm{m}$; it was carried out in a non-flow system, with a single-vessel filling. The sonication time was constant, at $\mathrm{t}=60 \mathrm{~s}$. The following chemical agents were used for the sludge preparation before the dewatering: cationic polyelectrolyte Zetag 8180 and inorganic coagulant PIX 113, in doses of 4.0, 5.0, 6.0, and 7.0 mg/g DM. The doses were within the range of optimal doses obtained in capillary suction time (CST) tests. In the case of Zetag 8180 polyelectrolyte, a solution of $0.1 \%$ was applied, while for inorganic coagulant PIX 113 a solution of $10 \%$ was used. The basic information on the chemical agents used in the tests is presented in Table 1.

Table 1. Characteristics of the chemicals used in the test.

\begin{tabular}{cl}
\hline Chemical Reagent & \multicolumn{1}{c}{ Description } \\
\hline PIX 113 & $\begin{array}{l}\text { A ferric coagulant, a dark brown water solution of ferric sulphate, } \\
\text { with total iron (Fe) content of } 11.4 \pm 12.2 \% \text {, and ironions } \mathrm{Fe}^{2+} \\
\text { content of } 0.4 \pm 0.3 \%[43,44]\end{array}$ \\
& $\begin{array}{l}\text { Copolymer of acrylamide and quaternized cationic monomer, } \\
\text { highly effective, supplied as off-white granular solid powder, } \\
\text { Zetag } 8180\end{array}$ \\
\hline
\end{tabular}

The prepared sludge samples were mixed using a Biosan MMS-3000N magnetic stirrer according to the following scheme. After adding chemical agents to the sonicated sludge, a rapid mixing was performed for a period of $60 \mathrm{~s}(200 \mathrm{rpm})$ in order to mix the samples thoroughly, and then a slow mixing for $300 \mathrm{~s}$ at $30 \mathrm{rpm}$ was applied. Next, centrifugation was used for the dewatering of the sludge samples. The dewatering process was carried out for five minutes with a rotation speed of $5000 \mathrm{rpm}$. The reject water was collected from the samples, and the following analyses were performed: $\mathrm{pH}$, by the potentiometric method (pH-meter CP401, Elmetron); total suspended solids (weight method); chemical oxygen demand (COD) according to (PN-ISO 6060:2006 [46]); and ammonium nitrogen and $\mathrm{PO}_{4}{ }^{-3}$ phosphates by the spectrophotometric method (Spectrophotometer JENWAY 6300). A test was performed three times for each sample, and the results are presented as a mean value. Table 2 presents the symbols assigned to the reject water samples obtained in the process of the dewatering of the sludge samples.

Table 2. Symbols assigned to the reject water samples.

\begin{tabular}{|c|c|c|}
\hline Lp & Symbol & Description \\
\hline 1. & RwNDS & Reject water from non-sonicated digested sludge \\
\hline 2. & $\begin{array}{l}\text { RwSDS1 } \\
\text { RwSDS2 } \\
\text { RwSDS3 }\end{array}$ & $\begin{array}{l}\text { Reject water from sonicated digested sludge. } \\
\text { The time of sonication 60s, the amplitude: } A_{1}=15.25 \mu \mathrm{m} \\
\text { (RwSDS1); } A_{2}=30.5 \mu \mathrm{m}\left(\text { RwSDS2); } A_{3}=45.75 \mu \mathrm{m}\right. \\
\text { (RwSDS3) respectively. }\end{array}$ \\
\hline 3. & $\begin{array}{l}\text { RwNDS + PIX113 } \\
\text { RwNDS + Zetag } 8180\end{array}$ & $\begin{array}{l}\text { Reject water from non-sonicated sludge prepared with chemical } \\
\text { reagents: PIX 113, Zetag } 8180\end{array}$ \\
\hline 4. & $\begin{array}{l}\text { RwSDS1 + PIX113 } \\
\text { RwSDS1 + Zetag } 8180\end{array}$ & $\begin{array}{l}\text { Reject water from sonicated digested sludge }\left(t=60 \mathrm{~s}, \mathrm{~A}_{1}=15.25 \mu \mathrm{m}\right) \\
\text { and chemically prepared with: PIX } 113 \text {, Zetag } 8180\end{array}$ \\
\hline 5. & $\begin{array}{l}\text { RwSDS2 + PIX113 } \\
\text { RwSDS2 + Zetag } 8180\end{array}$ & $\begin{array}{l}\text { Reject water from sonicated digested sludge }\left(t=60 \mathrm{~s}, \mathrm{~A}_{1}=30.5 \mu \mathrm{m}\right) \\
\text { and chemically prepared with: PIX } 113 \text {, Zetag } 8180\end{array}$ \\
\hline 6. & $\begin{array}{l}\text { RwSDS3 + PIX113 } \\
\text { RwSDS3 + Zetag } 8180\end{array}$ & $\begin{array}{l}\text { Reject water from sonicated digested sludge }\left(\mathrm{t}=60 \mathrm{~s}, \mathrm{~A}_{1}=45.75 \mu \mathrm{m}\right) \\
\text { and chemically prepared with: PIX } 113 \text {, Zetag } 8180\end{array}$ \\
\hline
\end{tabular}




\section{Results}

The characteristics of the reject water obtained in the process of the mechanical dewatering of non-sonicated digested sludge are presented in Table 3. The reject water demonstrated a very high concentration of ammonium nitrogen, at $1718 \mathrm{mgN}-\mathrm{NH}_{4}{ }^{+} / \mathrm{dm}^{3}$; phosphates, at $122.4 \mathrm{mgPO}_{4}{ }^{3-} / \mathrm{dm}^{3}$; and organic compounds. The COD of the reject water was found to be $2240 \mathrm{mgO}_{2} / \mathrm{dm}^{3}$.

Table 3. Characteristics of the reject water from non-sonicated digestion sludge.

\begin{tabular}{cccc}
\hline No & Indicator & Unit & Value \\
\hline 1 & $\mathrm{pH}$ & - & 7.32 \\
2 & Total suspended solids (TSS) & $\mathrm{mg} / \mathrm{dm}^{3}$ & 1142 \\
3 & Chemical oxygen demand (COD) & $\mathrm{mgO}_{2} / \mathrm{dm}^{3}$ & 2240 \\
4 & Ammonium nitrogen & $\mathrm{mgN-NH}_{4+} / \mathrm{dm}^{3}$ & 1718 \\
5 & Phosphates & $\mathrm{mgPO}_{4}^{-3} / \mathrm{dm}^{3}$ & 122.4 \\
6 & Phosphorus & ${\mathrm{mgP}-\mathrm{PO}_{4}}^{-3} / \mathrm{dm}^{3}$ & 40 \\
\hline
\end{tabular}

The results from the subsequent stages of the research are presented in Table 4. In the reject water obtained from the non-sonicated sludge prepared with inorganic coagulant PIX 113 , a decrease in the $\mathrm{pH}$ value was observed. The $\mathrm{pH}$ value decreased with the increasing dose of the coagulant. The lowest value of $\mathrm{pH}$ was observed for the dose of $7.0 \mathrm{mg} / \mathrm{g} \mathrm{DM}$; it was 5.02. The $\mathrm{pH}$ value decreased by $31.4 \%$ compared to the $\mathrm{pH}$ of 7.32 in the case of reject water from non-prepared digestion sludge. On the other hand, the $\mathrm{pH}$ value of the reject water obtained from non-sonicated sludge prepared with Zetag 8180 remained in a relatively narrow range of 7.43-7.47. This was not a significant change in relation to the $\mathrm{pH}$ value for reject water obtained from non-prepared sludge. Similar relationships in the $\mathrm{pH}$ values were obtained for reject water separated from sonicated sludge prepared with the selected chemical agents.

Table 4. Analysis of the reject water separated from prepared and non-prepared digested sludge.

\begin{tabular}{|c|c|c|c|c|c|c|c|}
\hline Parameter & Dose & $\mathrm{pH}$ & Phosphates & Phosphorus & $\begin{array}{l}\text { Ammonium } \\
\text { Nitrogen }\end{array}$ & COD & TSS \\
\hline Unit & $\mathrm{mg} / \mathrm{g} \mathrm{DM}$ & - & $\mathrm{mgPO}_{4}-3 / \mathrm{dm}^{3}$ & $\mathrm{mgP}^{-\mathrm{PO}_{4}}-3 / \mathrm{dm}^{3}$ & $\mathrm{~N}-\mathrm{NH}_{4}{ }^{+} / \mathrm{dm}^{3}$ & $\mathrm{mg} \mathrm{O} / \mathrm{dm}^{3}$ & $\mathrm{mg} / \mathrm{dm}^{3}$ \\
\hline \multicolumn{8}{|c|}{ Reject water separated from non-sonicated digested sludge prepared with: } \\
\hline \multirow{4}{*}{ PIX 113} & 4.0 & 6.27 & 10.1 & 3.3 & 1427 & 770 & 350 \\
\hline & 5.0 & 5.95 & 8.9 & 2.9 & 1155.7 & 500 & 300 \\
\hline & 6.0 & 5.56 & 7.0 & 2.3 & 984.8 & 320 & 260 \\
\hline & 7.0 & 5.02 & 4.3 & 1.4 & 969 & 280 & 110 \\
\hline \multirow{4}{*}{ Zetag 8180} & 4.0 & 7.43 & 50.5 & 16.5 & 1241.1 & 2230 & 540 \\
\hline & 5.0 & 7.44 & 41.6 & 13.6 & 788.4 & 1930 & 340 \\
\hline & 6.0 & 7.45 & 38.7 & 12.7 & 648.2 & 1850 & 240 \\
\hline & 7.0 & 7.47 & 26.6 & 8.7 & 612.7 & 1670 & 140 \\
\hline \multicolumn{8}{|c|}{ Reject water separated from sonicated $(\mathrm{A}=15.25 \mu \mathrm{m} ; \mathrm{t}=60 \mathrm{~s})$ sludge } \\
\hline & - & 7.8 & 215.2 & 70.3 & 853 & 3679.2 & 1083 \\
\hline \multicolumn{8}{|c|}{ and sludge prepared by: } \\
\hline \multirow{4}{*}{ PIX 113} & 4.0 & 5.9 & 24.9 & 8.1 & 703 & 1394.4 & 783.3 \\
\hline & 5.0 & 5.7 & 11.8 & 3.8 & 562 & 604.8 & 683.2 \\
\hline & 6.0 & 5.4 & 11.1 & 3.6 & 466 & 474 & 583.1 \\
\hline & 7.0 & 5.0 & 6.2 & 2.0 & 288 & 386.4 & 333.3 \\
\hline \multirow{4}{*}{ Zetag 8180} & 4.0 & 7.8 & 98.4 & 32.1 & 474 & 3354 & 500 \\
\hline & 5.0 & 7.8 & 95.3 & 31.1 & 286 & 2734.8 & 466.7 \\
\hline & 6.0 & 7.8 & 91.4 & 29.9 & 258 & 2614.4 & 383.3 \\
\hline & 7.0 & 7.9 & 68.4 & 22.3 & 206 & 2390.8 & 266.7 \\
\hline
\end{tabular}


Table 4. Cont.

\begin{tabular}{|c|c|c|c|c|c|c|c|}
\hline Parameter & Dose & $\mathrm{pH}$ & Phosphates & Phosphorus & $\begin{array}{l}\text { Ammonium } \\
\text { Nitrogen }\end{array}$ & COD & TSS \\
\hline Unit & $\mathrm{mg} / \mathrm{g} \mathrm{DM}$ & - & $\mathrm{mgPO}_{4}-3 / \mathrm{dm}^{3}$ & $\mathrm{mgP}^{-\mathrm{PO}_{4}}-3 / \mathrm{dm}^{3}$ & $\mathrm{~N}-\mathrm{NH}_{4}{ }^{+} / \mathrm{dm}^{3}$ & $\mathrm{mg} \mathrm{O} / \mathrm{dm}^{3}$ & $\mathrm{mg} / \mathrm{dm}^{3}$ \\
\hline \multicolumn{8}{|c|}{ Reject water separated from sonicated $(\mathrm{A}=30.5 \mu \mathrm{m} ; \mathrm{t}=60 \mathrm{~s})$ sludge } \\
\hline & - & 7.86 & 244.5 & 79.9 & 1354 & 3960 & 1230 \\
\hline \multicolumn{8}{|c|}{ and sludge prepared by: } \\
\hline \multirow{5}{*}{ PIX 113} & 4.0 & 6.4 & 63.0 & 20.6 & 1241.1 & 900 & 580 \\
\hline & 5.0 & 6.2 & 17.1 & 5.6 & 1155.7 & 590 & 470 \\
\hline & 6.0 & 5.8 & 15.9 & 5.2 & 1150.6 & 570 & 370 \\
\hline & 7.0 & 5.52 & 11.0 & 3.6 & 1040.1 & 400 & 310 \\
\hline & 4.0 & 7.88 & 156.7 & 51.2 & 1190.8 & 2880 & 770 \\
\hline \multirow{3}{*}{ Zetag 8180} & 5.0 & 7.89 & 134.9 & 44.1 & 1215.9 & 2800 & 560 \\
\hline & 6.0 & 7.90 & 131.9 & 43.1 & 803.9 & 2640 & 480 \\
\hline & 7.0 & 7.95 & 111.7 & 36.5 & 778.8 & 2400 & 440 \\
\hline \multicolumn{8}{|c|}{ Reject water separated from sonicated $(\mathrm{A}=47.75 \mu \mathrm{m} ; \mathrm{t}=60 \mathrm{~s})$ sludge } \\
\hline & - & 7.88 & 355.5 & 116.2 & 600 & 5260 & 2100 \\
\hline \multicolumn{8}{|c|}{ and sludge prepared by: } \\
\hline \multirow{5}{*}{ PIX 113} & 4.0 & 6.1 & 30 & 9.8 & 280 & 1172 & 766.7 \\
\hline & 5.0 & 5.8 & 23 & 7.5 & 260 & 862 & 533.3 \\
\hline & 6.0 & 5.4 & 8.8 & 2.9 & 240 & 689.6 & 483.3 \\
\hline & 7.0 & 5.1 & 7 & 2.3 & 200 & 586 & 466.6 \\
\hline & 4.0 & 7.9 & 332.5 & 108.7 & 498 & 5124 & 616.7 \\
\hline \multirow{3}{*}{ Zetag 8180} & 5.0 & 7.92 & 263 & 85.9 & 466 & 4987.4 & 516.7 \\
\hline & 6.0 & 7.93 & 230.5 & 75.3 & 261 & 4577.4 & 433.3 \\
\hline & 7.0 & 7.95 & 213 & 69.6 & 260 & 4440.8 & 400 \\
\hline
\end{tabular}

The amount of total suspended solids in the reject water in all cases decreased with the increase of the dose of the chemical reagents. The lowest value of TSS was $110 \mathrm{mg} / \mathrm{dm}^{3}$ for the reject water from the sludge prepared with PIX 113 at a dose of $7.0 \mathrm{mg} / \mathrm{g}$ DM. In this case, a high decrease of $91.2 \%$ concerning the TSS in the reject water from non-prepared sludge was observed. For the reject water from sonicated sludge $(A=15.25,30.5,45.75 \mu \mathrm{m})$ with the addition of PIX 113 at a dose of $7.0 \mathrm{mg} / \mathrm{g} \mathrm{DM}$, the following values were recorded, respectively: $333.3 \mathrm{mg} / \mathrm{dm}^{3}$ (a reduction of $69.2 \%$ ), $310 \mathrm{mg} / \mathrm{dm}^{3}$ (a reduction of $74.8 \%$ ), and $466.6 \mathrm{mg} / \mathrm{dm}^{3}$ (a reduction of $77.8 \%$ ).

In general, the COD decreased with the increasing dose of the applied chemical reagent in the reject water from the prepared sludge. The lowest COD value ( $280 \mathrm{mg}$ $\mathrm{O}_{2} / \mathrm{dm}^{3}$ ) was observed for the reject water obtained from non-sonicated sludge to which PIX 113 was added at a dose of $7.0 \mathrm{mg} / \mathrm{g}$ DM. This resulted in a reduction of COD at the level of $87.5 \%$. In the reject water from sonicated sludge $(A=15.25 ; 30.5 ; 45.75 \mu \mathrm{m})$ with the addition of PIX 113 at a dose of $7.0 \mathrm{mg} / \mathrm{g} \mathrm{DM}$, the following values were recorded: $386.4 \mathrm{mgO}_{2} / \mathrm{dm}^{3}$ (a reduction of $89.5 \%$ ), $400 \mathrm{mgO}_{2} / \mathrm{dm}^{3}$ (a reduction of $89.9 \%$ ), and $586 \mathrm{mgO}_{2} / \mathrm{dm}^{3}$ (a reduction of $88.8 \%$ ). The achieved reductions were significant for all of the cases.

For phosphates, a similar relationship was observed to that in the case of COD. The concentration of phosphates decreased with the increasing dose of the applied chemical reagent in the reject water samples. The lowest value of phosphates $\left(4.3 \mathrm{mgPO}_{4}{ }^{-3} / \mathrm{dm}^{3}\right)$ was achieved for the reject water from non-sonicated sludge in which PIX 113 was used at a dose of $7.0 \mathrm{mg} / \mathrm{g}$ DM. The reduction amounted to $96.5 \%$. For sludge sonicated with three different amplitudes $(15.25,30.5$, and $45.75 \mu \mathrm{m})$, and to which PIX 113 was added at a dose of $7.0 \mathrm{mg} / \mathrm{g} \mathrm{DM}$, the reduction of phosphates amounted, respectively, to $97.1 \%, 95.5 \%$, and $98 \%$. The PIX 113 coagulant bound and retained phosphates in the sludge proportionally to the applied dose. 
The lowest value of ammonium nitrogen was obtained for reject water separated from non-sonicated sludge with the addition of Zetag 8180 at a dose of $7.0 \mathrm{mg} / \mathrm{g} \mathrm{DM}$. It was $612.7 \mathrm{mg} \mathrm{N}-\mathrm{NH}_{4}{ }^{+} / \mathrm{dm}^{3}$. The reduction amounted to $64.3 \%$. For sonicated sludge $(\mathrm{A}=15.25,30.5$, and $45.75 \mu \mathrm{m})$ with the addition of Zetag 8180 at a dose of $7.0 \mathrm{mg} / \mathrm{g} \mathrm{DM}$, the lowest values of ammonium nitrogen were obtained: $206 \mathrm{mg} \mathrm{N}-\mathrm{NH}_{4}{ }^{+} / \mathrm{dm}^{3}$ (a reduction of $75.8 \%$ ), $778.8 \mathrm{mg} \mathrm{N}-\mathrm{NH}_{4}{ }^{+} / \mathrm{dm}^{3}$ (a reduction of $42.5 \%$ ), and $260 \mathrm{mg} \mathrm{N}-\mathrm{NH}_{4}{ }^{+} / \mathrm{dm}^{3}$ (a reduction of $66.7 \%$ ) respectively.

It can be concluded that the addition of the inorganic coagulant PIX 113 allows us to achieve better results in the reduction of impurities in reject water than polyelectrolyte Zetag 8180.

The concentration of organic compounds determined as COD in reject water increases with the amplitude of the ultrasonic field used for the sludge sonification. For non-sonicated sludge, the COD was $2240 \mathrm{mg} \mathrm{O}_{2} / \mathrm{dm}^{3}$. However, for sludge sonicated with three different amplitudes $(\mathrm{A}=15.25,30.5$, and $45.75 \mu \mathrm{m})$, the COD in the reject water was as follows: $3679.2 \mathrm{mg} \mathrm{O}_{2} / \mathrm{dm}^{3}, 3960 \mathrm{mg} \mathrm{O}_{2} / \mathrm{dm}^{3}$, and $5260 \mathrm{mg} \mathrm{O}_{2} / \mathrm{dm}^{3}$ respectively. The power of the ultrasonic field affects the amount of dissolved organic compounds. Then, after the addition of chemical agents to the sonicated digested sludge, the COD values in the reject water decrease with the increasing dose of the chemical agent (Figures 2 and 3).

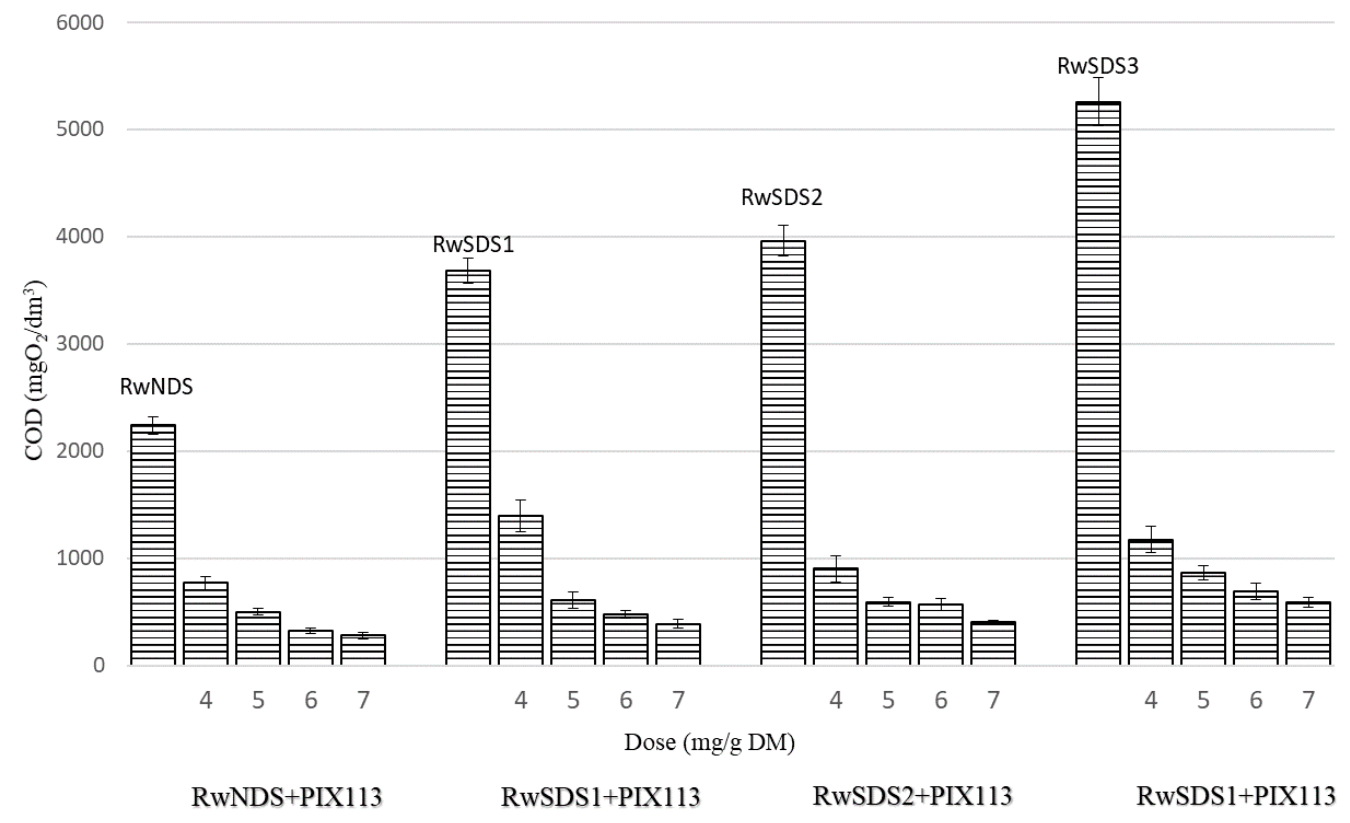

Figure 2. Changes of the COD in the reject water separated from sludge prepared with PIX 113.

The concentration of phosphates in the reject water, similarly to the COD, increased for the samples obtained from digested sewage sludge sonicated with an increasing amplitude of the ultrasonic field. The values of the phosphate concentration were as follows: $215.2 \mathrm{mgPO}_{4}{ }^{-3} / \mathrm{dm}^{3}, 244.5 \mathrm{mgPO}_{4}{ }^{-3} / \mathrm{dm}^{3}$, and $355.5 \mathrm{mgPO}_{4}{ }^{-3} / \mathrm{dm}^{3}$, respectively. The addition of chemical agents to the sludge sample led to a decrease of the phosphate concentration in the reject water. In particular, one can observe the effect of the use of PIX 113 on the decrease in the phosphate concentration (Figures 4 and 5). 


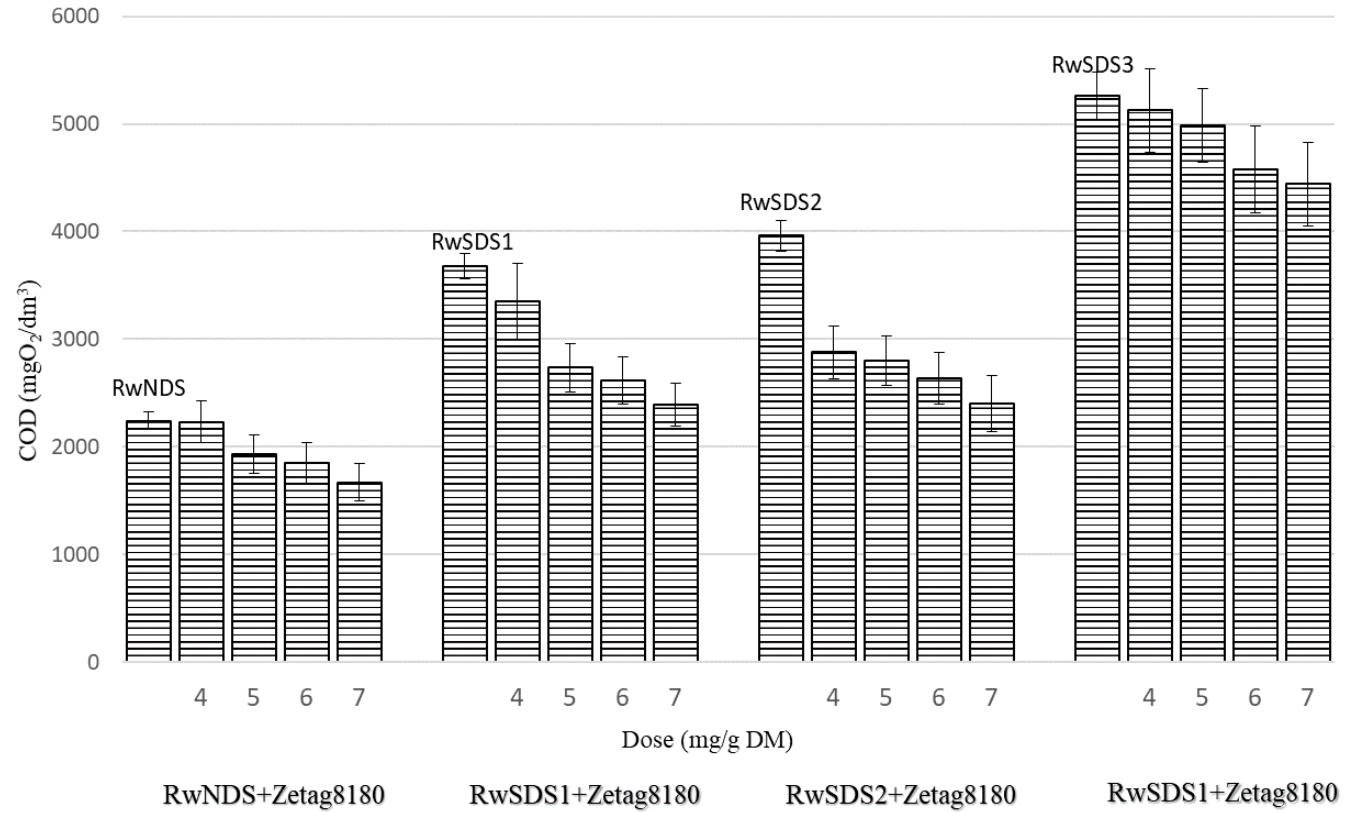

Figure 3. Changes of the COD in reject water separated from sludge prepared with Zetag 8180.

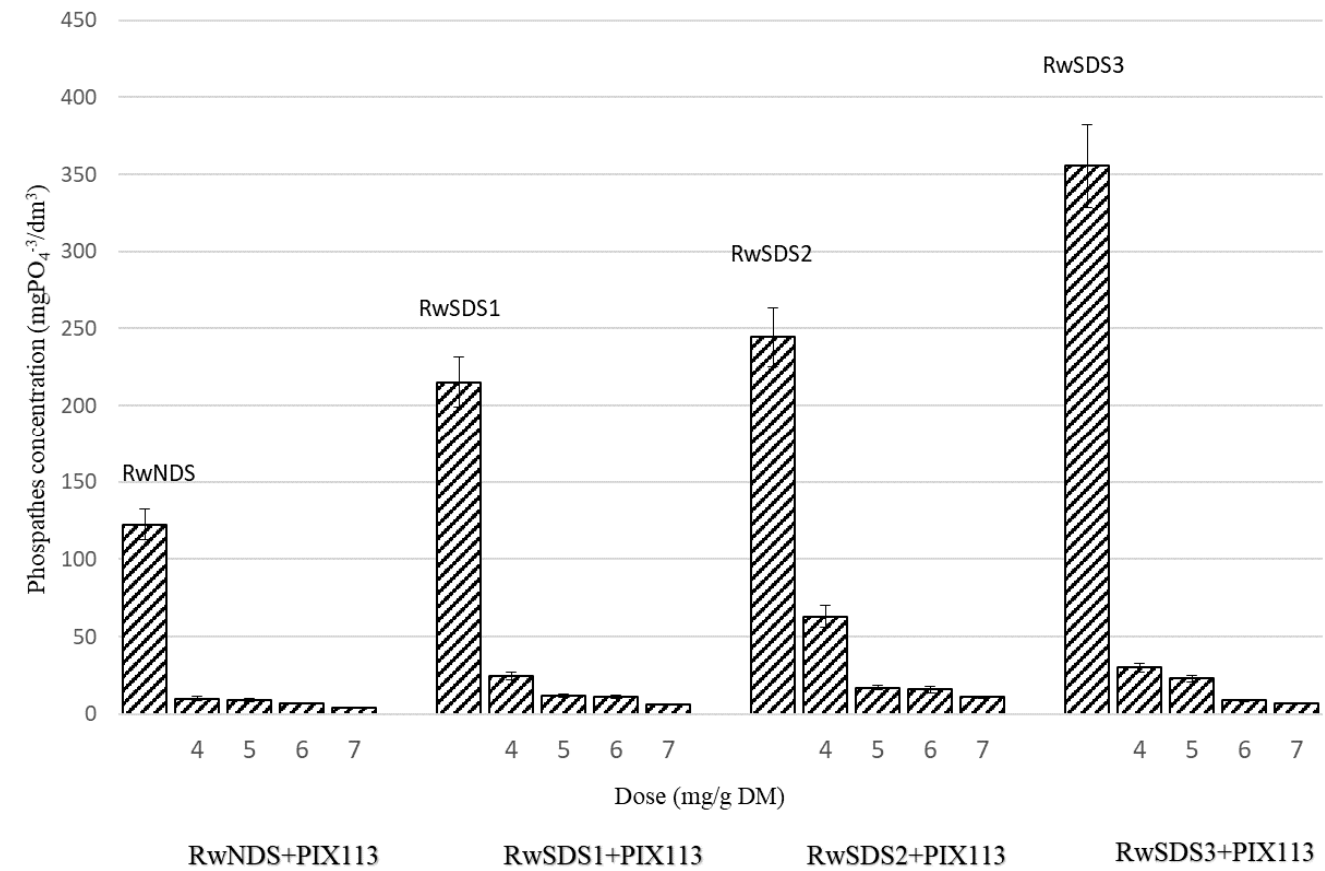

Figure 4. Changes of the phosphate concentration in the reject water separated from sludge prepared with PIX 113.

In the case of the ammonium nitrogen concentration in the reject water, it was observed that it decreased with the increasing amplitude of the ultrasonic field used for the sludge preparation. For non-sonicated sludge, the ammonium nitrogen concentration was $1718 \mathrm{mgN}-\mathrm{NH}_{4}{ }^{+} / \mathrm{dm}^{3}$. For sludge sonicated with three amplitudes $(\mathrm{A}=15.25,30.5$, and $45.75 \mu \mathrm{m}$ ) the concentration of ammonium nitrogen in the reject water amounted

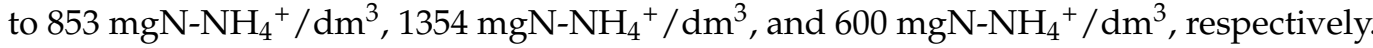
The concentration of ammonium nitrogen decreases with the increasing doses of applied chemicals (Figures 6 and 7). 


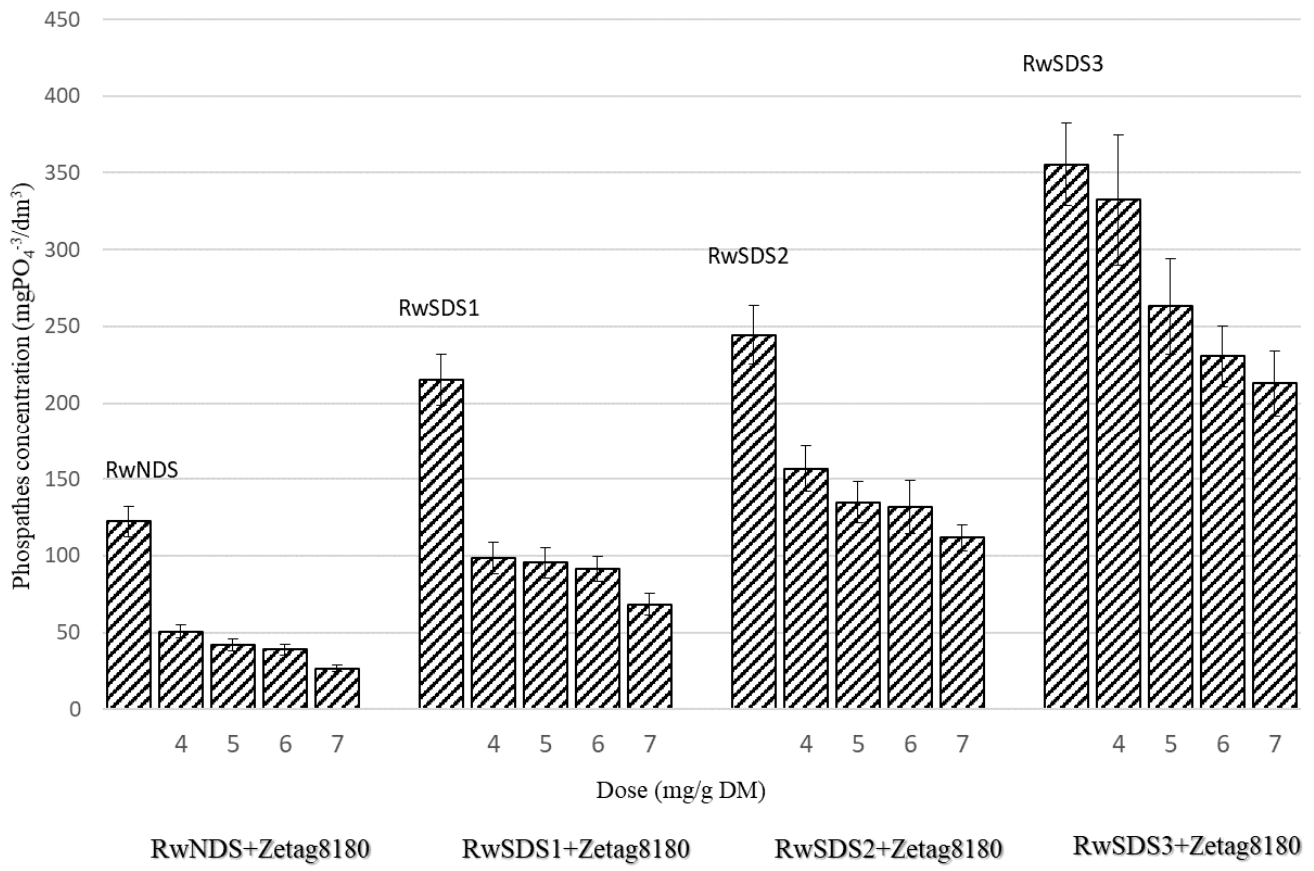

Figure 5. Changes of the phosphate concentration in reject water separated from sludge prepared with Zetag 8180.

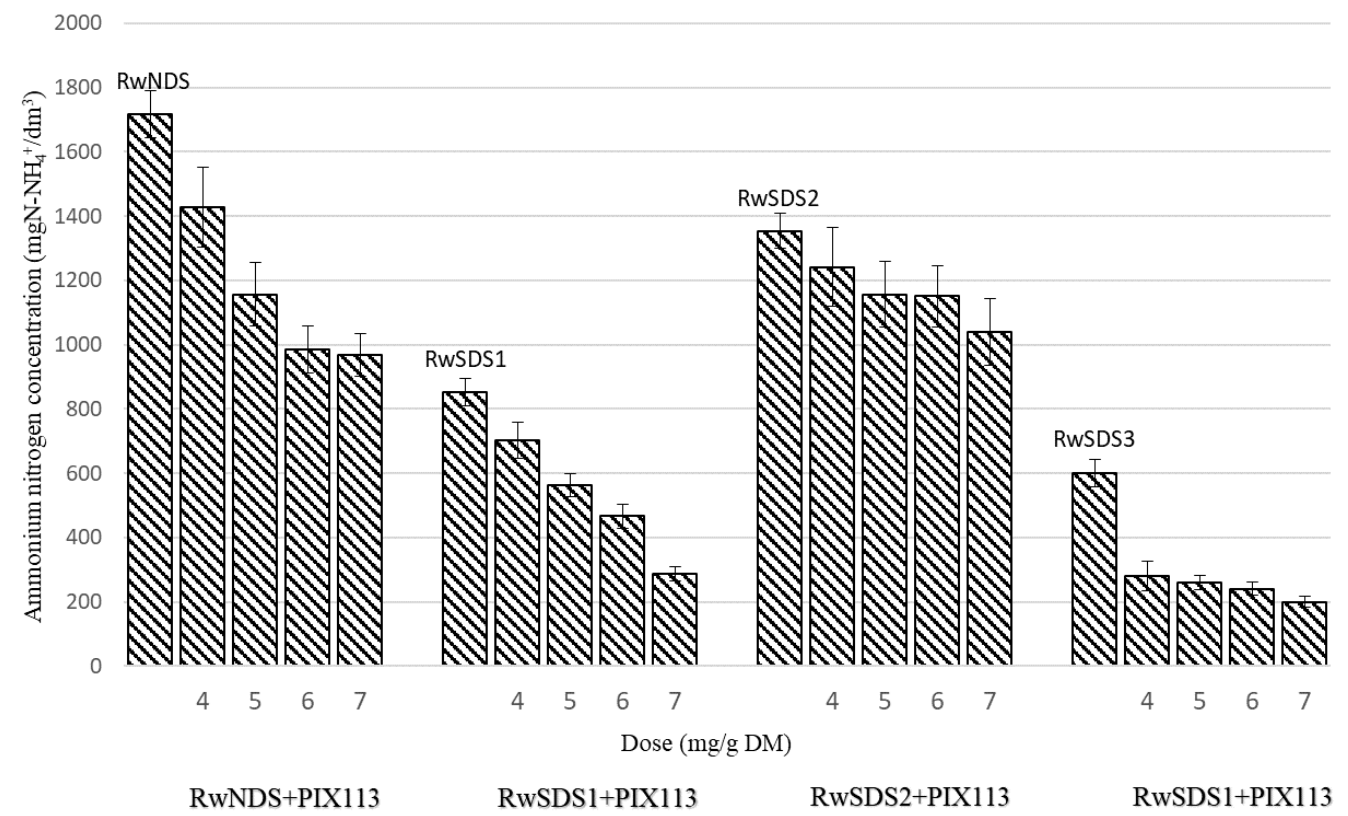

Figure 6. Changes of the ammonium nitrogen concentration in reject water separated from sludge prepared with PIX 113. 


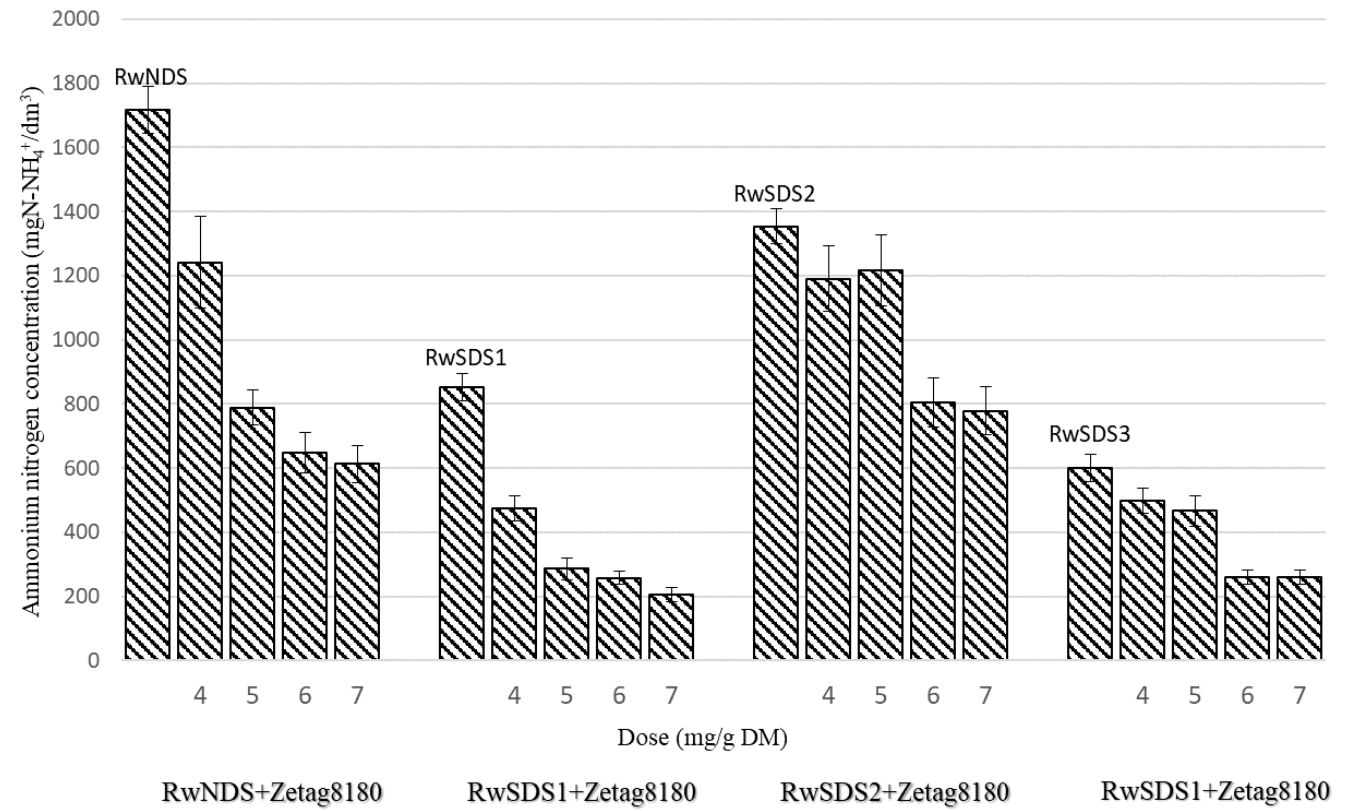

Figure 7. Changes of the ammonium nitrogen concentration in reject water separated from sludge prepared with Zetag 8180 .

\section{Discussion}

The disintegration of sewage sludge is aimed at breaking the bonds between microbial cells, destroying the cells with the release of organic substances, which affects the subsequent stages of sewage sludge processing [47-52]. The effect of ultrasonic disintegration is assessed on the basis of indicators such as sludge dewaterability, flocs structure and size changes, and the COD in reject water [53-55].

In the study, the authors analyzed the impact of ultrasonic disintegration and chemical conditioning methods on the $\mathrm{pH}, \mathrm{COD}$, phosphates, ammonium nitrogen and total suspended solids in the reject water obtained after the filtration of sewage sludge. Due to the disintegration of the sludge samples, the COD concentration in the reject water was higher than the concentration of COD in the reject water obtained after the filtration of non-sonicated sludge $\left(2240 \mathrm{mgO}_{2} / \mathrm{dm}^{3}\right)$, and the COD increased with an increase of the ultrasonic field's amplitude $(\mathrm{A}=15.25 ; 30.5 ; 45.75 \mu \mathrm{m})$ by $64.2 \%, 76.8 \%$, and $134.8 \%$ respectively (Figures 2 and 3). The increase in COD during sonication is related to the release of extracellular polymeric substances (EPS) during floc disintegration, and the release of cell components during cell lysis. Zawieja et al. [47] obtained similar dependencies in their research. They observed that with an increase of the power and the amplitude of the ultrasonic wave, the degree of liquefaction of the sludge increased, which was expressed as an increase in the COD. The highest efficiency in sludge biodegradability and COD increase was observed for the acoustic power of $1500 \mathrm{~W}$ [47]. Results obtained by Zhang et al. [56] showed that sonification effectively degrades and deactivates the sludge. The soluble chemical oxygen demand (sCOD) concentration increased with the increase of the sonication time and power density. The ultrasonic treatment for a period of $1800 \mathrm{~s}$ increased the sCOD by $690 \%$.

Ultrasonic disintegration caused an increase of phosphates in the reject water, too. The concentration of phosphates in the reject water increased with the increase of the ultrasonic field's amplitude. The basic phosphate concentration in the reject water after the filtration of non-sonicated sludge was $122.4 \mathrm{mgPO}_{4}{ }^{-3} / \mathrm{dm}^{3}$. After sonication with three different amplitudes $(\mathrm{A}=15.25,30.5$, and $45.75 \mu \mathrm{m})$, the concentration of phosphates increased respectively by $75.8 \%, 99.7 \%$, and $190.4 \%$ in the reject water samples (Figures 4 and 5). The concentration of phosphates in the reject water decreases with increasing doses of applied chemical agents. In the case of ammonium nitrogen concentration, no increase 
was found during the sonication process of digested sewage sludge. On the contrary, the concentration of ammonium nitrogen decreased in the reject water, respectively, by $50.3 \%$, $21.2 \%$, and $65.1 \%$ when the sludge was sonicated with three different amplitudes $(\mathrm{A}=15.25$, 30.5 , and $45.75 \mu \mathrm{m})$. The basic concentration of ammonium nitrogen in the reject water after the filtration of non-sonicated sludge was $1718 \mathrm{mg} \mathrm{N-NH}{ }_{4}^{+} / \mathrm{dm}^{3}$ (Figures 6 and 7). The decrease of ammonium nitrogen concentration is caused by the advanced oxidation of ammonium nitrogen by hydroxyl radicals. The mechanism of sonication is based on sonochemical reactions, i.e. pyrolytic reactions and cavitation. Pyrolytic reactions occur inside the cavitation bubbles formed by ultrasonic irradiation. In this way, free radicals such as $\mathrm{H}, \mathrm{OH}$, and $\mathrm{OH}_{2}$ are formed in a very short period. These radicals are involved in the rapid oxidation of organic and inorganic matter. When the chemical agents were added, the concentration of ammonium nitrogen decreased proportionally to the increased dose of chemicals. Negral et al. [57] analyzed changes in sCOD and $\mathrm{N}^{-\mathrm{NH}_{4}}{ }^{+}$using ultrasounds, enzymatic hydrolysis, and a combination of both pretreatment methods. They applied five ultrasonic energy powers: $3500,7000,10,500,14,000$ and $21,000 \mathrm{~kJ} / \mathrm{kg}$. The results showed an increase in SCOD with the increase of the energy power of the ultrasonic field. They also observed an increase in $\mathrm{N}-\mathrm{NH}_{4}{ }^{+}$in all of the cases, while in our work we observed a different relationship.

The problem of backloads from sludge management in wastewater treatment plants (WWTP) is ever more frequently noticed and undertaken in the literature on the subject [58-60]. Considering the amount of phosphorus and nitrogen in reject water, it is therefore worth asking the question "what is the right way to handle reject water at WWTP?" Should all of the untreated sludge liquids be included in the raw sewage stream? Or maybe we should just purify reject water from the load of biogenic compounds, as happens in some treatment plants. Another solution would be to look for methods of their recovery, especially given the deficit of nutrients in the environment. Obviously, recovery would be the best option. The results of the research demonstrated that the amount of biogenic compounds in reject water can be increased or decreased depending on how we intend to handle reject water at WWTPs.

\section{Conclusions}

- The concentration of COD in the reject water increased with the increase of the amplitude of the sonication wave. The use of chemical agents for sludge conditioning reduced the COD value in the reject water. The COD concentration decreased with the increase of the chemical dose. The best COD reduction effect (to $280 \mathrm{mgO}_{2} / \mathrm{dm}^{3}$ ) was observed for reject water obtained from non-sonicated sludge prepared with PIX 113 coagulant at a dose of $7.0 \mathrm{mg} / \mathrm{g}$ DM.

- The phosphate concentration in the reject water obtained from sonicated sludge increased along with the increase of the ultrasonic field's amplitude. However, it decreased with the increase of the dose of chemicals agents added to the sludge. The lowest value of phosphate concentration $\left(4.3 \mathrm{mgPO}_{4}{ }^{-3} / \mathrm{dm}^{3}\right)$ was observed for the reject water from non-sonicated sludge prepared with PIX 113 at a dose of $7.0 \mathrm{mg} / \mathrm{g}$ DM.

- The concentration of ammonium nitrogen in the reject water decreased with the increase of the amplitude of the ultrasonic field applied for the physical conditioning of the sludge. The addition of chemical agents to the sludge resulted in the further reduction in the concentration of ammonium nitrogen in the reject water. The lowest concentration of ammonium nitrogen $\left(200 \mathrm{mg} \mathrm{N}-\mathrm{NH}_{4}+/ \mathrm{dm}^{3}\right)$ was observed in the reject water obtained after the filtration of the sonicated sludge prepared with the addition of PIX 113 (at a dose of $7.0 \mathrm{mg} / \mathrm{g}$ DM).

- The sludge sonication increases the content of impurities (COD, phosphates) in the reject water along with an increase in the amplitude of the ultrasonic wave. The introduction of chemical agents causes a decrease of pollutants with an increase of the chemical dose. 
- $\quad$ PIX 113 coagulant gives much better results regarding the reduction of the impurities in the reject water than the polyelectrolyte Zetag 8180.

Author Contributions: Conceptualization, B.B.; methodology, B.B.; software, J.D.B.; validation, B.B., J.D.B.; formal analysis, B.B., J.D.B.; investigation, B.B.; resources, B.B.; data curation, J.D.B.; writing-original draft preparation, B.B.; writing—review and editing, J.D.B.; visualization, J.D.B.; supervision, B.B. All authors have read and agreed to the published version of the manuscript.

Funding: This research was funded by the statute subvention of Czestochowa University of Technology BS/PB-400-301/22, Faculty of Infrastructure and Environment.

Institutional Review Board Statement: Not applicable.

Informed Consent Statement: Not applicable.

Data Availability Statement: Not applicable.

Conflicts of Interest: The authors declare no conflict of interest. The funders had no role in the design of the study; in the collection, analyses, or interpretation of data; in the writing of the manuscript, or in the decision to publish the results.

\section{References}

1. Wójcik, M.; Stachowicz, F. Influence of physical, chemical and dual sewage sludge conditioning methods on the dewatering efficiency. Powder Technol. 2019, 344, 96-102. [CrossRef]

2. Zawieja, I.; Worwag, M. Biogas Production from excess sludge oxidized with peracetic acid (PAA). Energies 2021, $14,3434$. [CrossRef]

3. Chen, Z.; Afzal, M.T.; Salema, A.A. Microwave drying of wastewater sewage sludge. J. Clean Energy Technol. 2014, 2, 282-286. [CrossRef]

4. Wolny, L.; Wolski, P. Ultrasounds energy as an agent of polyelectrolyte modification prior to sewage sludge conditioning. Energies 2021, 14, 6165. [CrossRef]

5. Li, H.; Zou, S.; Li, C.; Jin, Y. Alkaline post-treatment for improved sludge anaerobic digestion. Bioresour. Technol. 2013, 140, 187-191. [CrossRef]

6. Kubacki, P.; Borowski, S. Physico-chemical characteristics and treatment methods of anaerobic supernatant. Przemysl. Chemiczny 2014, 93, 528-530.

7. Guo, C.H.; Stabnikov, V.; Ivanov, V. The removal of nitrogen and phosphorus from reject water of municipal wastewater treatment plant using ferric and nitrate bioreductions. Bioresour. Technol. 2010, 101, 3992-3999. [CrossRef]

8. Sperczyńska, E. Phosphates removal from reject water from digestion of sludge. Ecol. Eng. 2016, 48, 196-201. (In Polish)

9. Wang, S.; Yu, H.; Su, Q.; Zuo, J. Exploring the role of heterotrophs in partial nitritation-anammox process treating thermal hydrolysis process-Anaerobic digestion reject water. Bioresour. Technol. 2021, 341, 125762. [CrossRef]

10. Wang, W.G.; Xie, H.C.; Wang, H.; Xue, H.; Wang, J.J.; Zhou, M.; Dai, X.H.; Wang, Y.Y. Organic compounds evolution and sludge properties variation along partial nitritation and subsequent anammox processes treating reject water. Water Res. 2020, 184, 116197. [CrossRef]

11. Kim, I.-T.; Lee, Y.-E.; Jeong, Y.; Yoo, Y.-S. A novel method to remove nitrogen from reject water in wastewater treatment plants using a methane- and methanol-dependent bacterial consortium. Water Res. 2020, 172, 115512. [CrossRef] [PubMed]

12. Erdirençelebi, D.; Küçükhemek, M. Diagnosis of the anaerobic reject water effects on WWTP operational characteristics as a precursor of bulking and foaming. Water Sci. Technol. 2015, 71, 572-579. [CrossRef]

13. Myszograj, S. Quantity and characteristics of sludge liquids formed in wastewater treatment plants. Eng. Prot. Environ. 2008, 11, 219-227. (In Polish)

14. Morales, N.; Val del Río, A.; Vázquez-Padín, J.R.; Méndez, R.; Mosquera-Corral, A.; Campos, J.L. Integration of the Anammox process to the rejection water and mainstream lines of WWTPs. Chemosphere 2015, 140, 99-105. [CrossRef] [PubMed]

15. Dąbrowski, W.; Karolinczak, B.; Gajewska, M.; Wojciechowska, E. Application of subsurface vertical flow constructed wetlands to reject water treatment in dairy wastewater treatment plant. Environ. Technol. 2017, 38, 175-182. [CrossRef] [PubMed]

16. Rikmann, E.; Zekker, I.; Tenno, T.; Saluste, A.; Tenno, T. Inoculum-free start-up of biofilm- and sludge-based deammonification systems in pilot scale. J. Environ. Sci. Technol. 2018, 15, 133-148. [CrossRef]

17. Wett, B.; Podmirseg, S.B.; Gomez-Brandon, M.; Hell, M.; Nyhuis, G.; Bott, C.; Murthy, S. Expanding DEMON sidestream deammonification technology towards mainstream application. Water Environ. Res. 2015, 87, 2084-2089. [CrossRef]

18. Qian, Y.; Ding, Y.; Ma, H.; Chi, Y.; Yuan, H.-Y.; Li, Y.; Tian, S.; Zhang, B. Startup and performance of a novel single-stage partial nitritation/anammox system for reject water treatment. Bioresour. Technol. 2021, 321, 124432. [CrossRef]

19. Mehrdad, M.; Park, H.; Ramalingam, K.; Fillos, J.; Beckmann, K.; Deur, A.; Chandran, K. Anammox moving bed biofilm reactor pilot at the 26th Ward wastewater treatment plants in Brooklyn, New York: Start-up, biofilm population diversity and performance optimization. Water Sci. Technol. 2014, 70, 1448-1455. [CrossRef] 
20. Gu, Z.; Li, Y.; Yang, Y.; Xia, S.; Hermanowicz, S.W.; Alvarez-Cohen, L. Inhibition of anammox by sludge thermal hydrolysis and metagenomic insights. Bioresour. Technol. 2018, 270, 46-54. [CrossRef]

21. Sperczyńska, E. Use of zeolite for removal of ammonium nitrogen from reject water. Eng. Prot. Environ. 2016, 19, 391-399. (In Polish) [CrossRef]

22. Bień, B.; Bień, J. Conditioning of sewage sludge with physical, chemical and dual methods to improve Sewage sludge dewatering. Energies 2021, 14, 5079. [CrossRef]

23. $\mathrm{Wu}, \mathrm{X}$; Modin, $\mathrm{O}$. Ammonium recovery from reject water combined with hydrogen production in a bioelectrochemical reactor. Bioresour. Technol. 2013, 146, 530-536. [CrossRef] [PubMed]

24. Piaskowski, K.; Ćwikałowska, M. Profile of changes of orthophosphate concentrations during sewage and sewage sludge treatment. Rocz. Ochr. Sr. 2007, 9, 183-197.

25. Wang, R.; Li, Y.; Wang, W.; Chen, Y.; Vanrolleghem, P.A. Effect of high orthophosphate concentration on mesophilic anaerobic sludge digestion and its modeling. Chem. Eng. J. 2015, 260, 791-800. [CrossRef]

26. Battistoni, P.; Pavan, P.; Prisciandaro, M.; Cecchi, F. Struvite crystallization: A feasible and reliable way to fix phosphorus in anaerobic supernatants. Water Res. 2000, 34, 3033-3041. [CrossRef]

27. Claudia Santiviago, C.; Peralta, J.; López, I. Phosphorus removal from wastewater through struvite crystallization in a continuous fluidized-bed reactor: An improved comprehensive model. Chem. Eng. J. 2021, 430, 132903. [CrossRef]

28. Hong, T.; Wei, L.; Cui, K.; Chen, T.; Luo, L.; Fu, M.; Zhang, Q. A constant composition technique for quantifying the effect of As(V) on struvite crystallization under various operational conditions. J. Cryst. Growth 2020, 552, 125925. [CrossRef]

29. Mudragada, R.; Kundral, S.; Coro, E.; Moncholi, M.E.; Laha, S.; Tansel, B. Phosphorous removal during sludge dewatering to prevent struvite formation in sludge digesters by full scale evaluation. J. Water Process Eng. 2014, 2, 37-42. [CrossRef]

30. Ren, W.; Zhou, Z.; Jiang, L.M.; Hu, D.; Qiu, Z.; Wei, H.; Wang, L. A cost-effective method for the treatment of reject water from sludgedewatering process using supernatant from sludge lime stabilization. Sep. Purif. Technol. 2015, 142, 123-128. [CrossRef]

31. Podstawczyk, D.; Witek-Krowiak, A.; Dawiec-Liśniewska, A.; Chrobot, P.; Skrzypczak, D. Removal of ammonium and orthophosphates from reject water generated during dewatering of digested sewage sludge in municipal wastewater treatment plant using adsorption and membrane contactor system. J. Clean. Prod. 2017, 161, 277-287. [CrossRef]

32. Bradford-Hartke, Z.; Lane, J.; Lant, P.; Leslie, G. Environmental benefits and burdens of phosphorus recovery from municipal wastewater. Environ. Sci. Technol. 2015, 49, 8611-8622. [CrossRef] [PubMed]

33. Koskue, V.; Rinta-Kanto, J.M.; Freguia, S.; Ledezma, P.; Kokko, M. Optimising nitrogen recovery from reject water in a 3-chamber bioelectroconcentration cell. Sep. Purif. Technol. 2021, 264, 118428. [CrossRef]

34. Hao, X.; Wang, C.; Loosdrecht, M.C.M.; Hu, Y. Looking beyond struvite for P-recovery. Environ. Sci. Technol. 2013, 47, 4965-4966. [CrossRef] [PubMed]

35. Munir, M.T.; Li, B.; Boiarkina, I.; Baroutian, S.; Yu, W.; Young, B.R. Phosphate recovery from hydrothermally treated sewage sludge using struvite precipitation. Bioresour. Technol. 2017, 239, 171-179. [CrossRef]

36. Desloover, J.; Woldeyohannis, A.A.; Verstraete, W.; Boon, N.; Rabaey, K. Electrochemical resource recovery from digestate to prevent ammonia toxicity during anaerobic digestion. Environ. Sci. Technol. 2012, 46, 12209-12216. [CrossRef]

37. Koskue, V.; Freguia, S.; Ledezma, P.; Kokko, M. Efficient nitrogen removal and recovery from real digested sewage sludge reject water through electroconcentration. J. Environ. Chem. Eng. 2021, 9, 106286. [CrossRef]

38. Jermakka, J.; Thompson, E.; Ledezma, P.; Freguia, S. Electro-concentration for chemical-free nitrogen capture as solid ammonium bicarbonate. Sep. Purif. Technol. 2018, 203, 48-55. [CrossRef]

39. Ward, A.J.; Arola, K.; Brewster, E.T.; Mehta, C.M.; Batstone, D.J. Nutrient recovery from wastewater through pilot scale electrodialysis. Water Res. 2018, 135, 57-65. [CrossRef]

40. Bień, B.; Bień, J. Dewatering of sewage sludge treated by the combination of ultrasonic field and chemical methods. Desalin. Water Treat. 2020, 199, 72-78. [CrossRef]

41. Kamizela, T.; Kowalczyk, M. Impact of conditioning substances and filtration pressure on dewatering efficiency of sewage. Energies 2021, 14, 361. [CrossRef]

42. Hu, D.; Zhou, Z.; Niu, T.; Wei, H.; Dou, W.; Jiang, L.M.; Lv, Y. Co-treatment of reject water from sludge dewatering and supernatant from sludge lime stabilization process for nutrient removal: A cost-effective approach. Sep. Pur. Technol. 2017, 172, 357-365. [CrossRef]

43. Technologie Sanitarne. Available online: http://www.technologie-sanitarne.com/Koagulant_zelazowy_Pix_113_-3-205541-66_6 0_73.html (accessed on 22 January 2022).

44. Kemipol. Available online: http://www.old.kemipol.com.pl/img/pdf/karty_2009/20-1-K-PIX_113-SIARCZAN_VI_ZELAZA_ III_Xn.pdf (accessed on 22 January 2022).

45. Aniq. Available online: https://aniq.org.mx/pqta/pdf/Zetag_8180(HT).pdf (accessed on 22 January 2022).

46. PN-ISO 6060: 2006. Available online: http://sklep.pkn.pl/pn-iso-6060-2006p.html (accessed on 22 January 2022).

47. Zawieja, I.; Wolny, L. Effect of Sonicator Power on the Biodegradability of sewage sludge. Rocz. Ochr. Sr. 2011, 13, 1719-1730. (In Polish)

48. Molaey, R.; Yesil, H.; Calli, B.; Tugtas, A.E. Enhanced heavy metal leaching from sewage sludge through anaerobic fermentation and air-assisted ultrasonication. Chemosphere 2021, 279, 130548. [CrossRef] [PubMed] 
49. Kupczyk, K.; Zieliński, M.; Dębowski, M.; Szwarc, D.; Rokicka, M.; Hajduk, A. Utrasonic disintegration as a method of conditioning the biomass of microalgae Chlorella vulgaris before the process of methane fermentation. Logistyka 2015, 4, 9373-9378. (In Polish)

50. González-Fernández, C.; Sialve, B.; Bernet, N.; Steyer, J.P. Comparison of ultrasound and thermal pretreatment of Scenedesmus biomass on methane production. Bioresour. Technol. 2012, 110, 610-616. [CrossRef] [PubMed]

51. Tiehm, A.; Nickel, K.; Neis, U. The use of ultrasound to accelerate the anaerobic digestion of sewage sludge. Water Sci. Technol. 1997, 36, 121-128. [CrossRef]

52. Zhang, J.; Xu, D.; Zhang, G.; Ren, Z.; Zhu, Y. Critical review on ultrasound lysis-cryptic growth for sludge reduction. J. Environ. Chem. Eng. 2021, 9, 106263. [CrossRef]

53. Hajduk, A.; Dębowski, M.; Zieliński, M.; Kłodowska, I.; Rozpondek, P.; Rokicka, M.; Kupczyk, K.; Szwarc, D.; Łączyńska, B. Disintegration sludge in a loop reactor. Eko-Doc. Proc. 2015, 5, 150-157.

54. Rai, C.L.; Struenkmann, G.; Mueller, J.; Rao, P.G. Influence of ultrasonic disintegration on sludge growth reduction and its estimation by respirometry. Environ. Sci. Technol. 2004, 38, 5779-5785. [CrossRef]

55. Tiehm, A.; Nickel, K.; Zellhorn, M.; Neis, U. Ultrasonic waste activated sludge disintegration for improving anaerobic stabilization. Water Res. 2001, 35, 2003-2009. [CrossRef]

56. Zhang, P.; Zhang, G.; Wang, W. Ultrasonic treatment of biological sludge: Floc disintegration, cell lysis and inactivation. Bioresour. Technol. 2007, 98, 207-210. [CrossRef] [PubMed]

57. Negral, L.; Marañón, E.; Fernández-Nava, Y.; Castrillón, L. Short term evolution of soluble COD and ammonium in pre-treated sewage sludge by ultrasound and inverted phase fermentation. Chem. Eng. Process. 2013, 69, 44-51. [CrossRef]

58. Battistoni, P.; Paci, B.; Fatone, F.; Pavan, P. Phosphorus removal from anaerobic supernatants: Start-up and steady-state conditions of a fluidized bed reactor full-scale plant. Ind. Eng. Chem. Res. 2006, 45, 663-669. [CrossRef]

59. Ren, W.; Zhou, Z.; Wan, L.; Hu, D.; Jiang, L.M.; Wang, L. Optimization of phosphorus removal from reject water of sludge thickening and dewatering process through struvite precipitation. Desal. Water Treat. 2016, 57, 15515-15523. [CrossRef]

60. Yang, Y.; Zhao, Y.Q.; Babatunde, A.O.; Kearney, P. Two strategies for phosphorus removal from reject water of municipal wastewater treatment plant using alum sludge. Water Sci. Technol. 2009, 60, 3181-3188. [CrossRef] 